\section{ЗАХІДНОУКРАЇНСЬКІ ПРОЦЕСІЙНІ ХРЕСТИ ХVІІ-ХХІ СТОЛІТТЯ: ТИПОЛОГІЧНИЙ АСПЕКТ}

\author{
Золотарчук Наталія Ігорівна \\ Кандидат мистецтвознавства, доцент, \\ ORCID: 0000-0002-7503-9036, \\ e-mail: zicoo@ukr.net, \\ Університет Короля Данила, \\ вул. Коновальия, 35, Івано-Франківськ, Україна, 76000
}

Мета статті - проаналізувати типологію предметів церковної атрибутики; класифікувати їх за сукупністю зовнішніх формотворчих ознак для розпізнання; поділити на групи за часовою приналежністю, технологічним аспектом, матеріалом та художньою виразністю. Комплексне дослідження типології процесійних хрестів як специфічного художнього явища є актуальним і необхідним. Методологія дослідження полягає у застосуванні методів аналізу та синтезу, систематизації та узагальнення. Зокрема, компаративний метод аналізу застосовано для порівняння та співставлення речей церковного вжитку, а методика типологічного аналізу була необхідною для подання об’єктивних знань про діахронію, розкриття певної функціональної та композиційної спільності досліджуваних предметів. Наукова новизна дослідження визначається такими пріорітетами: комплексним висвітленням процесійних хрестів як специфічного художнього явища; виокремленням типологічних груп предметів церковної атрибутики (літургійні, запрестольні) процесійних хрестів з позиції системного підходу, що дало змогу виділити поняття архетипу. Висновки. Встановлено, що важливою особливістю типології сакральних пам'яток мистецтва $€$ те, що вона не лише дає змогу охопити наявні типи, а й указує на створення нових параметрів художньої системи. Доведено, що сакральні предмети варто класифікувати за певними критеріями, передусім, за принципом формотворення. Виявлено, що розпізнанню процесійних хрестів сприяє сукупність зовнішніх формотворчих ознак. Сакральні предмети церковного вжитку (процесійні хрести), які мають спільні конструктивно-формотворчі ознаки і декоруючі техніки класифіковано та поділено на групи за часовою ознакою, технікою виконання, декором, іконографічною схемою, матеріалом, стилістикою виконання. 3'ясовано вплив матеріалів на естетичне сприйняття й композицію декорування.

Ключові слова: процесійні хрести; типологія; церковна атрибутика

\title{
Вступ
}

Процесійні хрести (виносні, запрестольні) утворюють окрему типологічну групу літургійних (Станкевич, 2002, с. 282). Їхнє дослідження ускладнюється неналежним збереженням пам'яток, особливо давнішніх. Наприкінці XIX - на початку XX ст. переважали типові ознаки народної творчості. Декорування предметів церковного вжитку більшою мірою грунтувалося на народних традиціях. Однак $з$ часом започаткувалися, розвинулися принципи, які засновувалися на інноваціях у формотворенні та композиційних нововведеннях. Новаторські ідеї вплинули на стилістику створення сакральних предметів та їхню форму, а також змінили манеру виконання. Художнє вирішення процесійних атрибутів детермінували різні чинники, зокрема фізичні властивості матеріалу, технологія, традиційний декор.

Наукова новизна дослідження полягає у спробі систематизації відомостей про предмети церковного вжитку, серед яких є чимало оригінальних творчих засобів. Передбачено класифікування творів iз врахуванням найважливіших ознак художньої системи та комплексне висвітлення процесійних хрестів. Виокремлення типологічної групи цих предметів (літургійні, запрестольні, процесійні) з позиції системного підходу надалі дасть змогу виділити поняття архетипу (найдавніший стійкий, консервативний праобраз ідей, схему типів).

Підгрунтям для дослідження процесійних хрестів стала проаналізована та систематизована джерельна база. Основу дослідження становить обсяг наукових праць таких дослідників, як В. Свєнціцька (1939), М. Драган (1970), Р. Одрехівський (1998), М. Станкевич (2002; 2003), М. Приймич (2001; 2007), I. Дундяк (2003; 2005), В. Лукань (2004).

Подані науковцями факти стали вагомим вкладом для нашого дослідження, а саме: інформація щодо типології культових та обрядових предметів, зокрема дерев'яних хрестів XVII-XX ст. і їх функ-

(C) Золотарчук Н. I., 2019 
ціонування, про стилістику українського дерев'яного різьблення (Свєнціцька, 1939; Драган, 1970), питання класифікації різьблених богослужбових хрестів та основні тенденції розвитку різьбярства на Лемківщині кінця XIX-XX ст. (Одрехівський, 1998, с. 70-87), систематизація та аналіз творів сакрального мистецтва, зокрема подано коротку характеристику процесійних хрестів (Приймич, 2001; Приймич, 2007), розкриття малодосліджених аспектів українських процесійних ікон та хрестів як оригінального явища українського мистецтва в літургійному дійстві (Дундяк, 2003; 2005), також у розвідках наведено вичерпну інформацію про процесійні хрести й патериці із карпатських теренів (Лукань, 2004). Слід відзначити працю М. Станкевича (2002), де проаналізовано процесійні хрести (виносні) XV ст., кінця XVIII, початку XIX-XX ст.

Незважаючи на наукове зацікавлення пам'ятками сакрального мистецтва Західної України, предмети церковної атрибутики недостатньою мірою висвітлюються в дослідженнях мистецтвознавців.

У процесі осмислення обраної теми послуговуємося результатами досліджень науковців, праці яких спорадично висвітлюють проблематику процесійних хрестів. Аналіз наукової літератури засвідчує відсутність комплексної праці, тому є очевидною потреба продовження дослідницьких пошуків 3 метою грунтовного висвітлення означеної теми.

\section{Мета статті}

Метою статті є здійснення порівняльного і мистецтвознавчого аналізу процесійних хрестів у чіткій злагодженій системі, що сприятиме стилістичному розпізнанню творів. Мета роботи реалізується шляхом виконання таких завдань: дослідити предмети релігійного призначення; класифікувати їх за критеріями: сукупністю зовнішніх формотворчих ознак, поділом на групи, за технологічним аспектом.

\section{Виклад матеріалу дослідження}

Типологія є своєрідною теоретичною основою для дослідження сакральних творів, ключовим розумінням їхніх декоративних засад (Станкевич, 2002, с. 196). «Жоден з видів системи декоративного мистецтва не має такої багатої типології творів, як художнє дерево» (Станкевич, 2002, с. 9). Автор демонструє твори сакрального мистецтва - придорожні, ручні, напрестольні i, зокрема, процесійні хрести.

Типологічний підхід створює можливість для подання порівняльного й мистецтвознавчого аналізу в чіткій злагодженій системі. Його застосування в дослідженні сприяє стилістичному розпізнанню творів (Радченко, 2009, с. 32-36; Радченко, 2006, с. 62-63). Типологія досліджуваних творів сприяє розрізненню церковних атрибутів за поширеним типом - предмети літургійного призначення.

Стале поєднання однотипних предметів відносимо до типологічної групи. Важливою особливістю типології $€$ те, що вона дає змогу охопити не лише наявні типи, а й указує на створення нових параметрів художньої системи. У цьому плані типологічна група має певну функційну особливість та композиційну спільність кількох досліджуваних предметів, вирізняється сукупністю зовнішніх формотворних ознак, які сприяють ії розпізнанню (Станкевич, 2002, с. 193-194).

Сакральні предмети варто класифікувати за певними критеріями, передусім, за принципом формотворення ${ }^{1}$ (Рис. 1). Треба звернути увагу на вирізнення таких хрестів, як грецький (чотирикінцевий 3 усіма рівними, іноді розширеними кінцями); латинський (чотирикінцевий із видовженим вертикальним раменом) (Станкевич. ред, 1996, с. 3-27).

Хрест в українському мистецтві можна класифікувати за типами: чотирикінцевий (грецького та римського підтипів), шести- та семикінцевий (із подовженою середньою поперечкою, семикінцевий із рівними раменами), восьмикінцевий із похилою нижньою поперечкою, антропоморфний, свастика, трійчастий (Станкевич, 2002; Золотарчук, 2015; 2018).

В основу систематизації покладено різні підходи, які належать типологічним групам творів. Перший параметр передбачає виділення загальних форм (Станкевич, 2002, с. 247-248).

Сукупність деяких зовнішніх формотворчих ознак сприяє розпізнанню процесійних хрестів. Характеризуючи побудову хрестів, водночас вважаємо за доцільне зауважити, що у відношенні до стрижня два перехрестя (верхнє та нижнє) приблизно однакової довжини, хоча середнє рамено з незначним видовженням. Типовими зразками цієї групи можна вважати двосторонній процесійний хрест XVII ст.

\footnotetext{
${ }^{1}$ Розробники схеми типології процесійних хрестів Станкевич М., Золотарчук Н.
} 
із теренів Лемківщини, колишнє с. Рихвалд (тепер Овчари, Польща), що зберігається в історичному музеї в Сяноку, та односторонній хрест невідомого майстра у виставковій залі катехитичного центру при катедральному соборі Святого Воскресіння м. Івано-Франківська.

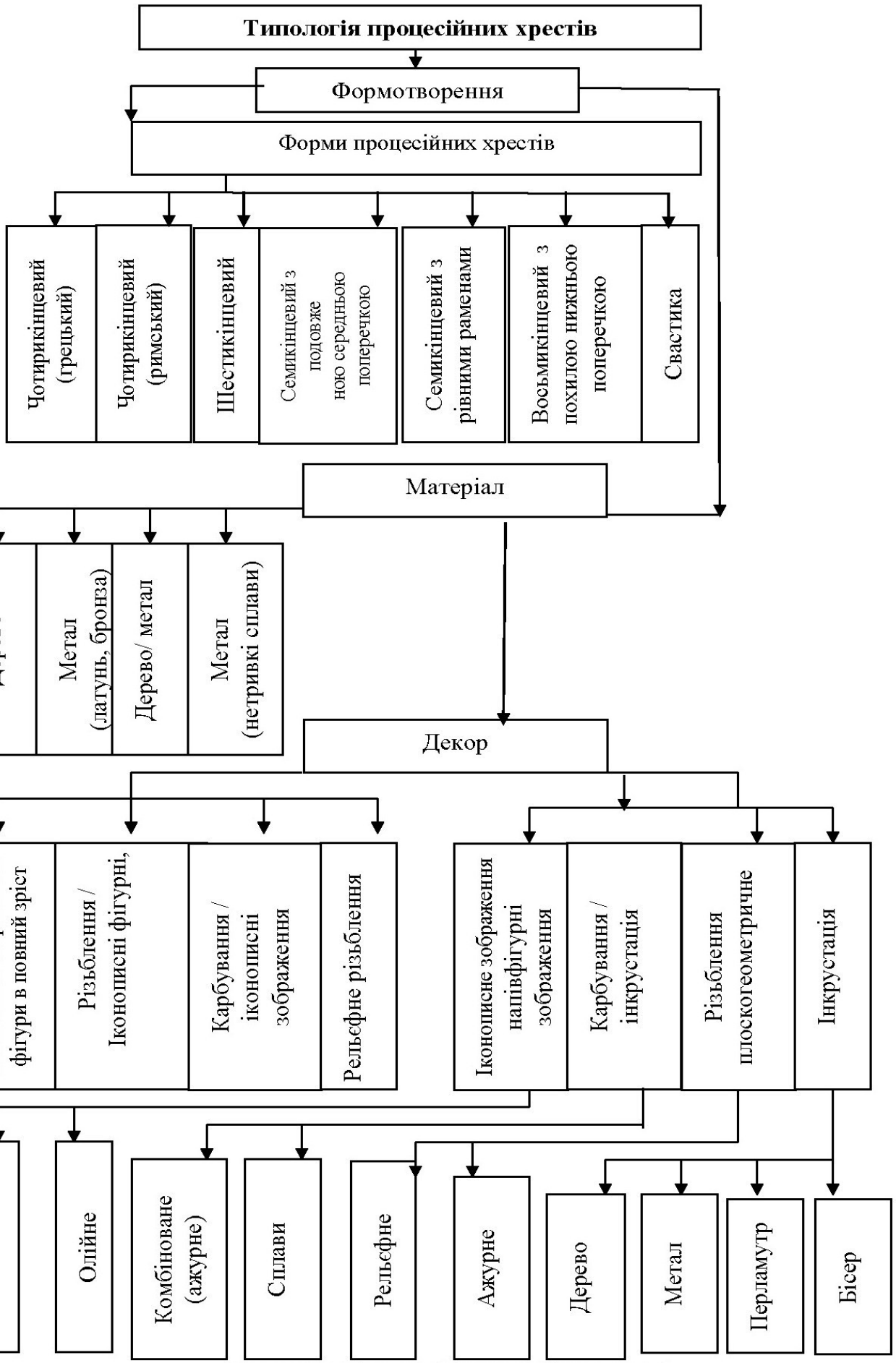

Рисунок 1. Типологія процесійних хрестів

Figure 1. Typology of the processional crosses

Двосторонній процесійний хрест 1756 р. з Рогатинщини (в експозиції Івано-Франківського музею мистецтв Прикарпаття та односторонній хрест для процесій другої половини XVIII ст. церкви св. Димитрія в с. Семидуби Дубницького р-ну (збережений в експозиції краєзнавчого музею м. Рівного) позначений аналогічною зовнішньою формою, але з різнобіжністю поперечиць (переважно скісних) (Золотарчук, $2015 ; 2018)$. 
Хрести поділяються на групи за часовою ознакою. Відомий в Україні грецький хрест свідчить про давнє походження, як, наприклад, найстаріший двосторонній процесійний хрест Галичини XV ст. (с. Городиська Старосамбірського р-ну Львівської області) правильної квадратної форми - перехрестя $\epsilon$ рівномірно видовжені, профільовані. Особливо цінним $є$ цей найстаріший український хрест для процесій XV ст., із двостороннім живописним зображенням на площині. Це багатофігурні сцени на релігійну тематику, трактовані із пластичною виразністю та чіткістю пропорцій (зберігається у Львівському музеї народної архітектури та побуту) (Станкевич, 2002, с. 282-285; Золотарчук (2015; 2018)).

Процесійні хрести кінця XVIII ст. із с. Хмелівки, с. Іванківці з Буковини, а також датовані початком XIX ст. з Лемківщини, с. Репецьке (Польща) мають форму трилистих хрестових закінчень, які на завершеннях рамен творять короткі перехрестя.

Процесійний хрест початку XX ст. латинського типу (чотирикінцевий із видовженим вертикальним раменом), який знаходиться в експозиції Косівського музею народного мистецтва та побуту Гуцульщини із характерним рідковживаним декоративним елементом півмісяця в його основі (Лукань, 2004, с. 190).

Графічне зображення у вигляді хреста, а саме монограмічні зображення різних форм, що символізували життя та божество, відоме ще до часів християнства. Хрещатість чотирьох грецьких літер Г («гамма») у вигляді хреста, відоме як свастика (символ кругового сонячного руху, тобто життя), використовується у рельєфному, ажурному зображеннях процесійного хреста XVIII ст. із Гуцульщини.

За технікою виконання (другий параметр) можливий поділ за технологічними ознаками: найбільшу групу становлять процесійні хрести з дерева - із плоским різьбленням (XV-XVIII ст.), темперним живописом (XV ст.), з рельєфним різьбленням, розмалюванням (XVIII-XIX ст.), із металу (кінця XVIII-XIX ст.), поєднання дерева з металом (XX ст.). У взаємозумовленості та взаємозалежності дерева й металу як основному принципі технологічного творення домінантним незмінно залишається дерево.

Декор процесійних хрестів здебільшого залежав від зміни стилів. Розглянуті нами твори, декоровані фігуративною пластикою - Розп'яттями та рельєфною різьбою, за характером пластичного трактування умовно поділяємо на: а) фігури із традиційно народною манерою виконання як наслідування іконних зображень; б) правдоподібне трактування фігури, виконані за взірцем академічної пластики. 3 матеріалів досліджень М. Станкевича можна дізнатися про стильові відмінності прецесійних хрестів, що виражені в різьбленні з певними локальними художніми особливостями. Науковець слушно зазначає: «3 характерними ознаками рельєфного, круглого, ажурного різьблення та поліхромування виступають три процесійні хрести 3 церкви в Криворівні Верховинського р-ну (Гуцульщина, остання чверть XVIII століття)» (Станкевич, 2002, с. 287) (Рис. 2, 3).

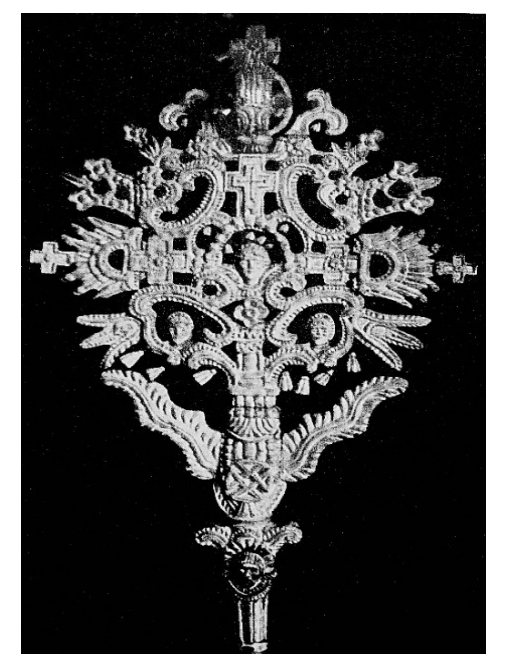

Рисунок 2. Виносний хрест кінця XVIII ст., дерево, профілювання, плоско-ажурна різьба, поліхромування. Гуцульщина, с. Криворівня Верховинського р-ну (світлина М. Станкевича)

Figure 2. Outside cross, the end of the $18^{\text {th }}$ century, wood, profiling, flat-pierced work, polychrome. Hutsul region, the village of Kryvorivnia, Verkhovyna district (image of M. Stankevych)

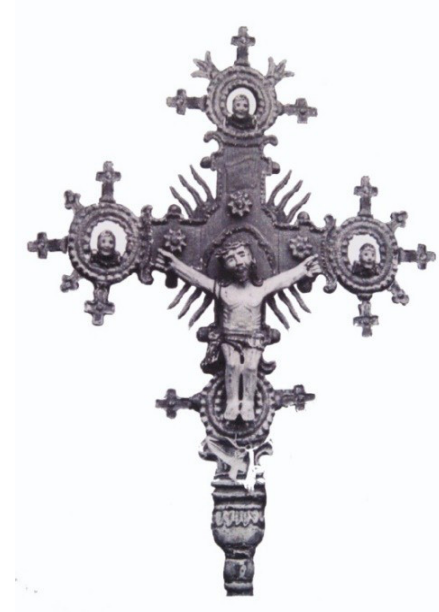

Рисунок 3. Процесійний хрест кінця XVIII ст., дерево, профілювання, рельєфно-ажурна різьба, поліхромування. Гуцульщина, с. Криворівня Верховинського р-ну (світлина М. Станкевича)

Figure 3. Processional cross, the end of the $18^{\text {th }}$ century, wood, profiling, relief-pierced work, polychrome. Hutsul region, the village of Kryvorivnia, Verkhovyna district (image of M. Stankevych) 
За його твердженням, автор різьблення не намагався реалістично відтворити в рельєфі зображення Розп'яття, висота якого невелика й майже не виділяється в центрі середохрестя, а безпосередньо звертав увагу на сакралізацію хреста декоративним антуражем (орнаментальне тло багате знаками-мотивами голівками ангелів, маленькими хрестиками, колами, ромбами, квітками-розетами.

Використання мотивних знаків простежується в процесійних хрестах кінця XVIII - початку XIX століть на Гуцульщині (с. Криворівня та в с. Бистрець) (Станкевич, 2002, с. 287-289).

На червоному тлі фігурно профільованого процесійного хреста XIX ст. 3 церкви Успіння Св. Анни с. Бистрець Верховинського р-ну Івано-Франківської області розміщене позолочене Розп'яття, виконане в народній манері: видовжені руки та надто малого розміру ноги (Рис. 4). На завершеннях хреста круглої форми, з обох сторін від Розп'яття, містяться декоративні голівки-маскарони (верхня з крилами). Із середохрестя виходять хвилясті промені. На тлі хреста помітні різьблені доповнення: вгорі, над фігурою Спасителя, дощечка з написами, поверх якої розміщено голуба - символ Святого Духа, а нижче - череп із кістками, які символізують Череповище (інше символічне значення - останки Адама, першої, створеної Богом людини), обабіч розіп'ятого Ісуса - зірочки. Оздоблює хрест різьблений елемент S-подібної конфігурації (нагадує морського коника), прикріплений маленьким дармовисом, наявні також зіркоподібні квітки на стеблі з округлим листям, які декорують рамена хреста вище Розп'яття.

Центрове зображення процесійного хреста 1893 р. $з$ церкви Успіння Св. Анни с. Бистрець Верховинського р-ну Івано-Франківської області має на декорованому стояку невелике поліхромоване Розп'яття в народній манері виконання (Рис 5). Із середохрестя виходять звивисті промені вгору та трилисники донизу. Кожні завершення хреста виконані у вигляді свастики, поєднаної із хрещатими хрестиками, що сполучувані поміж собою маленькими завитками та квітками. Декороване поєднання внизу - поєднання трьох хрестиків - нагадує нижню перекладину.

Найуживанішим матеріалом у виготовленні досліджуваних сакральних атрибутів є деревина різної породи. Для різьблення та інкрустацій використовуються переважно тверді породи дерев - груша, бук, клен. Виготовляють вироби столярним або токарним способом. Для прикрашення сакрального предмета підбирають відповідні мотиви. В орнаментиці використовують стародавні знаки «сонечко», «зірочки», характерні для розпису писанок, мотиви природних рослинних форм. Отже, можемо виокремити типологічну групу за наступною технікою виконання.

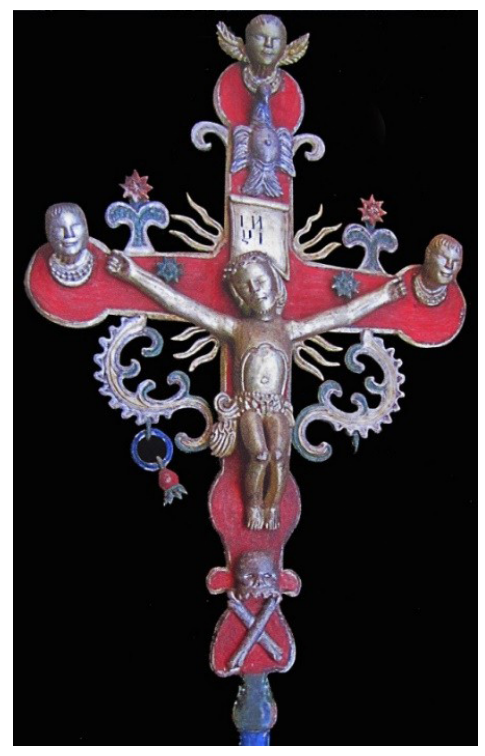

Рисунок 4. Процесійний хрест XIX ст., дерево, різьба, поліхромія, імітація позолоти, (213×81×10,5см).

Церква Успіня Св. Анни с. Бистрець Верховинського р-ну Івано-Франківської обл. (світлина А. Кіся)

Figure 4. Processional cross of the $19^{\text {th }}$ century, wood, carving, polychrome, imitation of gilding,

(213x81x10,5 cm). The Church of Dormition of Saint Anne, village of Bystrets of Verkhovyna district, Ivano-Frankivsk region (image of A. Kis)

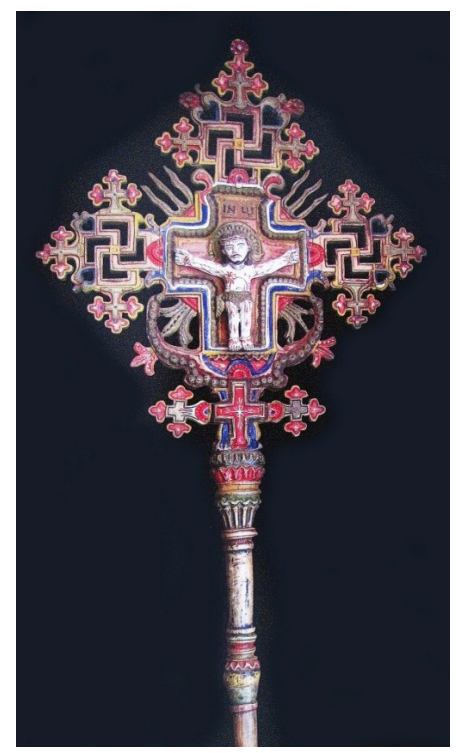

Рисунок 5. Процесійний хрест 1893 р., дерево, рельєфна різьба, поліхромія, (205х76х9,5см). Церква Успіня Св. Анни с. Бистрець Верховинського району Івано-Франківської обл. (світлина А. Кіся)

Figure 5. Processional cross of 1893, wood, relief carving, polychrome, $(205 \times 76 \times 9,5 \mathrm{~cm})$. The Church of Dormition of Saint Anne, village of Bystrets of Verkhovyna district, Ivano-Frankivsk region (image of A. Kis) 
Попри численні особливості, упродовж XX ст. збереглися унікальні зразки, що мають традиційні відмінні акценти в декоруванні. Відзначимо також традицію застосування в декорі церковної атрибутики додаткових матеріалів (бісер, метал, перламутр), що надають оригінальної фактури предметам, а також збагачують їх візуальними ефектами.

Наприкінці XIX - на початку XX ст. у декоруванні творів мистецтва з'являється інкрустація різноманітними шматками дерева, перламутру, бісером та металом - кусочками бляхи, крученим дротом. Вони позначені певною індивідуальною манерою виконання, оригінальною в своєму тлумаченні та цікавою в оздобленні. Так, у техніці вирізування, точіння, інкрустації досить лаконічно виконаний процесійний хрест майстрів з Гуцульщини початку XX ст. Цей взірець $є$ в експозиції Косівського музею народного мистецтва (Лукань, 2004).

Окрім дерев'яних, можна виділити ще один тип хрестів - металеві процесійні. Тому варто типологізувати сакральні твори відповідно до матеріалу виконання - литі, карбовані, комбіновані. Часто трапляються зразки із рельєфною різьбою фігур чи ажурним різьбленням. На особливу увагу заслуговують процесійні хрести XIX ст. Завдяки оригінальним варіантам з ускладненими мотивами змінювалося сприйняття художньої образності твору (Золотарчук, 2018).

Із появою нових матеріалів і технологій з'являються нововведення у виготовленні сакральних предметів, де для підсилення декорування нерідко використовують рельєфні литі композиції. Причиною популярності культового лиття стала високохудожня й технічна якість досліджуваних атрибутів, у композиціях яких застосовувалися такі самі, як і в живописних сюжетах, що прикрашають хрести.

В інвентарних книгах Музею історії релігії м. Львова зафіксовано відомості про процесійний уніатський хрест XX ст. (144х37×24 см.), виготовлений у техніці литва (латунь-сталь), який походив і3 церкви Івана Хрестителя м. Городок Львівської області.

Варто взяти до уваги взаємозалежність дерева та металу. Використання таких металів, як латунь і мідь, у XXI ст. трапляються рідше, а більшою мірою майстри використовують метал нетривких корозійних сплавів. Технологія й естетичні характеристики матеріалів, що визначають декоративність досліджуваних об'єктів, мають важливе значення в художній обробці дерева й металу (Золотарчук, 2018).

За іконографічним матеріалом (третій параметр) поділяють на різновиди: в іконографічних типах зображень на процесійних хрестах простежуються шляхи їх формування та визначається образна типологія христологічного, марієлогічного, агіографічного циклів: за способом розташування, характером постави, особливостями зображення.

Іконографія сакральних атрибутів залежала від іконографічних першовзірців, що функціонували в чітких сюжетних межах. Для систематизації їх класифіковано згідно із провідним мотивом. Збереглося найбільше варіантів Господнього циклу та Богородичних зображень.

Зображення процесійного хреста XVII-XVIII ст. с. Сколе Сколівського р-ну Львівської області, як і обидва хрести XIX ст. з Національного музею у Львові імені Митрополита А. Шептицького, об'єднані за єдиною іконографічною схемою. Це підтверджує представлена цілофігурна постать Ісуса Христа, уміщена на цілій площині хреста (Золотарчук, 2015, с. 101-102).

Індивідуальні образи постаті Богородиці репрезентують особливості мистецьких уподобань - про це свідчать одноосібні зображення Богоматері на процесійних хрестах. Таку рідкісну для українського іконопису іконографічну схему та iï нетрадиційне вирішення знаходимо на процесійному хресті з експозиції катехитичного центру, що при катедральному соборі Святого Воскресіння м. Івано-Франківська. Це процесійний хрест, що не має датування, виконаний невідомим автором. Він шестикінцевий, дощатої конструкції, односторонній, із прямою підніжкою, із зображенням видовженої фігури Богоматері в червоному мафорії зі схрещеними на грудях руками та похиленою головою. Зображення подане на синьому тлі, воно об'ємно промодельоване за допомогою світлотіні. Певною мірою до зазначеної іконографії тяжіє процесійний хрест зі збірки Національного Львівського Музею. Зворотнє зображення висвітленого атрибуту - це постать Пресвятої Діви в повний зріст (Золотарчук, 2015, с. 104-105).

В іконографії західноукраїнських ікономалярських зображень чільне місце відводиться агіографічним сюжетам, які містять образи святих та мучеників.

В агіографічних сюжетах, як на попередньо розглянутих процесійних хрестах, датованих переважно XVII-XVIII ст., часто бачимо мотив ангела, що вказує на постійне покровительство ангелів над людьми. Знаковою постаттю в агіографічних композиціях є Св. Миколай. У небесній ієрархії Миколай Чудотворець, другий після Богородиці. Традиційна для його образу іконографічна схема - фронтальне зображення, півпостать у єпископському вбранні, у лівій руці книга, правицею благословляє, що наближає його до канонічного образу Христа. Наприклад, на хресті для процесій XV ст. із Львівського 


\section{ОБРАЗОТВОРЧЕ ТА ДЕКОРАТИВНО-УЖИТКОВЕ МИСТЕЦТВО}

ISSN 2410-1176 (Print) • Вісник КНУКіМ. Серія: Мистецтвознавство. Вип. 41 • ISSN 2616-4183 (Online)

музею народної архітектури і побуту, у якому властивості кольору - барвистість, світлість, насиченість - підсилюють статичність чи динамічність композиційних сюжетів. Тут у творенні художньої виразності позитивну роль відіграють матеріали, оскільки вони впливають на естетичне сприйняття та композицію декору.

За четвертим параметром - стилістикою виконання - виокремлюємо: народний «примітивний» у техніці виконання та способі інтерпретації; напівпрофесійний з більшим фаховим складником; професійний, де процесійні предмети відзначаються високою вправністю виконання (іконографічні, різьбярські та металеві проробки площини й деталей).

\section{Висновки}

Науково обгрунтована типологія процесійних хрестів сприяє художньо-стильовому аналізу творів. Систематизовано сакральні атрибути культового призначення із характерними візуальними ознаками, що сприяло точній науковій ідентифікації.

Досліджуючи атрибути як предмети релігійного призначення, ми класифікували їх за певними критеріями: зовнішні формотворчі ознаки; хронологічні межі; технологічний аспект; особливості матеріалу та художньої виразності, що суттєво впливає на рівень художньої цінності твору.

3'ясовано вплив матеріалів на естетичне сприйняття й композицію декорування. Концепція проявляється в традиції - тісному зв'язку із художньою спадщиною, який історично визначився в канонічності, традиційності та новаторстві. Більшою мірою на народних традиціях базувалося декорування предметів церковного вжитку. Однак із часом сформувалися нові принципи, які базувалися на новаціях у формотворенні та композиційних нововведеннях. Новаторські ідеї вплинули на створення форм сакральних предметів і стилістичні зміни в манері виконання.

Для отримання цілісного уявлення про типологію процесійних атрибутів важливо розкрити їхнє функційне навантаження, а також виявити ознаки, на основі яких грунтується порівняння й досягається потрібний стилістичний ефект. Усе це становить перспективи подальших досліджень.

\section{Список бібліографічних посилань}

Боньковська, С.М. (Упоряд.). (1996). Хрест в украӥнському мистещътві: каталог виставки. Львів: Інститут народознавства НАН України.

Драган, М. (1970). Украӥнська декоративна різьба XVI-XVIII століть. Київ: Наукова думка.

Дундяк, I.M. (2003). Проиесійні ікони Західної України XVII-XIX століть. Походження, іконографічні тахудожні особливості. (Дисертація кандидата мистецтвознавства). Львівська академія мистецтв, Львів.

Дундяк, I.M. (2005). Мистецькі особливості західноукраїнських церковних процесій XVII-XVIII століть. Вісник Прикарпатського університету: Мистецтвознавство, 8, 28-35.

Золотарчук, Н. (2012). Іконографія процесійних хрестів і патериць XVII-XIX століть. В Мистецтвознавство’12: проблеми, публікації, панорама подій (с. 215-224). Львів: СКІМ.

Золотарчук, Н. (2015). Процесійні хрести та патериці Західної України XVII-XXI століть (традииї, новаторство, xудожні особливості). (Дисертація кандидата мистецтвознавства). Прикарпатський національний Університет імені Василя Стефаника, Івано-Франківськ.

Золотарчук, Н. (2018). Процесійні хрести та патериці Західної України XVII-XIX століття: типологія, іконографія. Science Review, 3(10), 7, 63-68.

Кузенко, П. (2007). Еволюція знаку хреста в процесі культуротворення. Художня культура. Актуальні проблеми, 4, 609-617.

Лукань, В. (2004). Процесійні хрести та патериці на Гуцульщині XVII-XX століть. Вісник Прикарпатського національного університету: Мистецтвознавство, 6, 184-192.

Одрехівський, Р. (1998). Різьбярство Лемківщчини: від давнини до сьогодення. Львів: Сполом.

Приймич, М. (2001). Декоративне різьблення у сакральному мистецтві Закарпаття XVIII-XIX століть (Iсторія. Типологія. Художньо-стильові особливості). (Дисертація кандидата мистецтвознавства). Львівська академія мистецтв, Львів.

Приймич, М. (2007). Перед лицем твоӥм. Закарпатський іконостас. Ужгород: Карпати-Гражда.

Радченко, А. (2006). Типологія декоративних деталей міської архітектури Гуцульщини і Покуття кінця XIX першої третини ХХ століття. Вісник Прикарпатського університету: Мистеитвознавство, 10-11, 32-36. 
Радченко, А. (2009). Дерев'яний та металевий декор у міській архітектурі Гуиульщини і Покуття наприкінці $X I X$ - $y$ першій третині XX століття (генезис, типологія, стилістика). (Дисертація кандидата мистецтвознавства). Інститут народознавства НАН України, Львів.

Свєнціцька, В. (1939). Українські різьблені ручні хрести XVII-XX віків. Львів.

Станкевич, М. (2002). Украӥнське художне дерево XVI-XX століть. Львів.

Станкевич, М. (2003). Проблеми теорії дослідження пластичних мистецтв. В Мистецтвознавство'02: проблеми, публікації, панорама подій (с. 14-15). Львів: СКІМ.

Філоненко, М. (1996). Хрест. В А. Колодний, \& Б. Лобовик (Ред.), Релігієзнавчий словник. Київ: Четверта хвиля.

\section{References}

Bonkovska, S.M. (Comp.). (1996). Khrest v ukrainskomu mystetstvi: kataloh vystavky [Cross in the Ukrainian art: catalogue of exhibition]. Lviv: The Ethnology Institute National Academy of Sciences of Ukraine [in Ukrainian].

Drahan, M. (1970). Ukrainska dekoratyvna rizba XVI-XVIII stolit [Ukrainian ornamental cut of the $16^{\text {th }}-18^{\text {th }}$ centuries]. Kyiv: Naukova dumka [in Ukrainian].

Dundiak, I.M. (2003). Protsesiini ikony Zakhidnoi Ukrainy XVII-XIX stolit. Pokhodzhennia, ikonohrafichni ta khudozhni osoblyvosti [Processional icons of Western Ukraine of the $17^{\text {th }}-19^{\text {th }}$ centuries. Origin, iconographic and artistic features]. (PhD Dissertation). Lviv National Academy of Arts, Lviv [in Ukrainian].

Dundiak, I.M. (2005). Mystetski osoblyvosti zakhidnoukrainskykh tserkovnykh protsesii XVII-XVIII stolit [Artistic features of Western Ukrainian ecclesiastical processions of the $17^{\text {th }}-18^{\text {th }}$ centuries]. Visnyk Prykarpatskoho universytetu: Mystetstvoznavstvo, 8, 28-35 [in Ukrainian].

Filonenko, M. (1996). Khrest [Cross]. In A. Kolodnyi, \& B. Lobovyk (Eds.), Relihiieznavchyi slovnyk [The Religious Dictionary]. Kyiv: Chetverta khvylia [in Ukrainian].

Kuzenko, P. (2007). Evoliutsiia znaku khresta v protsesi kulturotvorennia [The evolution of the sign of the cross in the process of cultural creation]. Artistic culture. Topical issues, 4, 609-617 [in Ukrainian].

Lukan, V. (2004). Protsesiini khresty ta paterytsi na Hutsulshchyni XVII-XX stolit [Processional crosses and crutches in the Hutsul region of the $17^{\text {th }}-20^{\text {th }}$ centuries]. Visnyk Prykarpatskoho natsionalnoho universytetu: Mystetstvoznavstvo, 6, 184-192 [in Ukrainian].

Odrekhivskyi, R. (1998). Rizbiarstvo Lemkivshchyny: vid davnyny do sohodennia [Carving of Lemkivshchyna: from ancient times to the present]. Lviv: Spolom [in Ukrainian].

Pryimych, M. (2001). Dekoratyvne rizblennia u sakralnomu mystetstvi Zakarpattia XVIII-XIX stolit (Istoriia. Typolohiia. Khudozhno-stylovi osoblyvosti) [Decorative carving in the sacral art of Zakarpattia region of the $18^{\text {th }}-19^{\text {th }}$ centuries (History. Typology. Artistic and stylistic features)]. (PhD Dissertation). Lviv National Academy of Arts, Lviv [in Ukrainian].

Pryimych, M. (2007). Pered lytsem tvoim. Zakarpatskyi ikonostas [In front of your face. Iconostasis of Zakarpattia]. Uzhhorod: Karpaty-Hrazhda [in Ukrainian].

Radchenko, A. (2006). Typolohiia dekoratyvnykh detalei miskoi arkhitektury Hutsulshchyny i Pokuttia kintsia XIX pershoi tretyny XX stolittia [Typology of decorative details of urban architecture of the Hutsul and Pokuttia regions of the late nineteenth - the first third of the twentieth century]. Visnyk Prykarpatskoho universytetu: Mystetstvoznavstvo, X-XI, 32-36 [in Ukrainian].

Radchenko, A. (2009). Derevianyi ta metalevyi dekor u miskii arkhitekturi Hutsulshchyny i Pokuttia naprykintsi XIXu pershii tretyni XX stolittia (henezys, typolohiia, stylistyka) [Wooden and metal decor in the urban architecture of the Hutsul and Pokuttia regions at the end of the $19^{\text {th }}$ - in the first part of $20^{\text {th }}$ century (genesis, typology, stylistics)]. (PhD Dissertation). The Ethnology Institute National Academy of Sciences of Ukraine, Lviv [in Ukrainian].

Stankevych, M. (2002). Ukrainske khudozhnie derevo XVI-XX stolit [Ukrainian Art Tree of the $16^{\text {th }}-20^{\text {th }}$ Centuries]. Lviv [in Ukrainian].

Stankevych, M. (2003). Problemy teorii doslidzhennia plastychnykh mystetstv [Issues of the theory of the study of plastic arts]. Art Studies '02: Problems, Publications, Panorama of Events (pp. 14-15). Lviv: SKIM [in Ukrainian].

Svientsitska, V. (1939). Ukrainski rizbleni ruchni khresty XVII-XX vikiv [Ukrainian hand carved crosses of the $17^{\text {th }}-20^{\text {th }}$ centuries]. Lviv [in Ukrainian].

Zolotarchuk, N. (2012). Ikonohrafiia protsesiinykh khrestiv i pateryts XVII-XIX stolit [Iconography of processional crosses and crutches of the $17^{\text {th }}-19^{\text {th }}$ centuries]. In Art Studies'12: Problems, Publications, Panorama of Events (pp. 215-224). Lviv: SKIM [in Ukrainian].

Zolotarchuk, N. (2015). Protsesiini khresty ta paterytsi Zakhidnoi Ukrainy XVII-XXI stolit (tradytsii, novatorstvo, khudozhni osoblyvosti) [The processional crosses and crutches of Western Ukraine of the $17^{\text {th }}-21^{\text {st }}$ centuries 
(traditions, innovations, artistic features)]. (PhD Dissertation). Vasyl Stefanyk Precarpathian National University, Ivano-Frankivsk [in Ukrainian].

Zolotarchuk, N. (2018). Protsesiini khresty ta paterytsi Zakhidnoi Ukrainy XVII-XIX stolittia: typolohiia, ikonohrafiia [The processional crosses and verges of Western Ukraine of the 1 $17^{\text {th }}-19^{\text {th }}$ century: typology, iconography]. Science Review, 3(10), 7, 63-68 [in Ukrainian].

Стаття надійшла до редакиії: 16.10.2019

\section{ЗАПАДНОУКРАИНСКИЕ | Золотарчук Наталия Игоревна ПРОЦЕССИОННЫЕ КРЕСТЫ Кандидат искусствоведения, доџент, XVII-XXI СТОЛЕТИЯ: Университет Короля Данила, ТИПОЛОГИЧЕСКИЙ АСПЕКТ}

Цель статьи - проанализировать типологию предметов церковной атрибутики; классифицировать их за общностью внешних формообразующих признаков для розпознания; разделить на группы по временной принадлежности, технологическому аспекту, материалу и художественной выразительности. Комплексное исследование типологии процессионных крестов как специфического художественного явления является актуальным и необходимым. Методология исследования заключается в применении методов анализа и синтеза, систематизации и обобщения. В частности, компаративный метод анализа применено для сравнения и сопоставления вещей церковной утвари, а методика типологического анализа была необходимой для представления обьективных знаний о диахронии, раскрытия (толкования) определённой функциональной и композиционной общности исследуемых предметов. Научная новизна исследования определяется такими приоритетами: комплексным освещением происхождения и развития прецессионных крестов как специфического художественного явления; выделением типологических групп предметов церковной атрибутики (литургические, запрестольные) прецессионных крестов с позиции системного подхода, что дало возможность выделить понятие архитипа. Выводы. Установлено, что важной особенностью типологии сакральных памятников искусства является то, что она позволяет охватить не только имеющиеся типы, но и указывает на создание новых параметров художественной системы. Доказано, что сакральные предметы следует классифицировать по определенным критериям, прежде всего по принципу формообразования. Выявлено, что распознанию процессионных крестов способствует совокупность внешних формообразующих признаков. Сакральные предметы церковного обихода (процессионные кресты), которые имеют общие конструктивно-формообразующие признаки и декорирующие техники классифицированы и разделены на группы по временному признаку, технике исполнения, декору, иконографической схеме, материалу, стилистике исполнения. Выяснено влияние материалов на эстетическое восприятие и композицию декорирования.

Ключевые слова: процессионные кресты; типология; церковная атрибутика

\section{PROCESSIONAL CROSSES OF $\mid$ Nataliia Zolotarchuk WESTERN UKRAINE OF THE $\mathbf{1 7}^{\mathrm{TH}} \mathbf{- 2 1}^{\mathrm{ST}}$ PhD in Art History, Associate Professor, CENTURIES: TYPOLOGICAL ASPECT King Danylo University, Ivano-Frankivsk, Ukraine}

The purpose of the article is to analyze the typology of the objects of the church attributes; to classify them on the basis of external form-creating identification features; divide them into groups depending on the time they belong to, technological aspect, material and artistic expression. A comprehensive analysis of the typology of the processional crosses as a specific art phenomenon is relevant and necessary. The research methodology is the application of such methods as: analysis and synthesis, systematization and generalization. In particular, a comparative analysis was applied to compare and correlate items of the church use, and the typological analysis was necessary to provide objective knowledge of diachrony and reveal common character of certain functional and compositional features of the studied subjects. The scientific novelty of the research is determined by the following priorities: complex presentation of processional crosses as a particular art phenomenon; the identification of typological groups of objects of church attributes (liturgical, sanctuary) - processional crosses from the standpoint of the systematic approach which allowed distinguishing the concept of archetype. Conclusions. 
It was determined that the important feature of the typology of sacred art items is that it both involves the existing types and indicates the creation of new parameters of the art system. It was proved that sacred objects should be classified according to certain criteria, first of all, according to the principle of formation. It was revealed that recognition of processional crosses is facilitated by the set of external form-creating features. The sacred items of the church use (processional crosses) having the common design and forming features, decorating techniques are classified and divided into groups by time, technique, decoration, iconographic scheme, material, style of execution. The influence of materials on the aesthetic perception and composition of the decoration was studied.

Keywords: processional crosses; typology; church attributes 